DOI: http://dx.doi.org/10.11157/sites-vol1oissiid231

- ARTICLE -

\title{
WHAKAPAPA AND METAMORPHOSIS
}

\author{
Margaret Kawharu
}

\begin{abstract}
In the context of running Treaty of Waitangi claims against the Crown, ${ }^{1}$ I argue that the claim process is much more about what it means to be Maori, on ever shifting ground in New Zealand society, than anything else. There are three stages in the claim process once a claim is lodged: presentation of evidence, negotiations around appropriate redress and an agreed settlement. At every stage in the process, claimants are required to identify themselves in terms of their whakapapa (genealogy). Yet the fact that these terms have been determined by the Crown is in itself a result of patterns of interaction shaped by a legal, adversarial settlement process and an iniquitous colonial past. This essay aims to clarify why the claim process is so protracted and what challenges the Maori claimants face, when the very process of being eligible to engage with the Crown forces them to redefine their identity as Maori several times over. In doing so the essay points to the tension for Maori between working with indigenous concepts and values at the same time as engaging with the Crown to settle long-standing grievances. It also addresses some key anthropological questions about identity processes, showing how being claimants reinforces, embraces and strengthens the notion of a Maori identity but at the same time undermines, systematises, and limits being Maori. In this sense, one understands how the Crown, or the state, is an institution 'that is the ground of both our freedoms and our unfreedoms' (Scott, 1998:7).
\end{abstract}

\section{INTRODUCTION}

James Scott's (1998) ideas about 'statecraft' provide a useful lens through which to understand the claim process. Like most states, the Crown is fixed on the homogenisation of its citizens, hegemonic planning, abstractions and formulaic simplifications. Jeff Sissons (1993) points out that the systematisation of many aspects of being Maori illustrates the commitment of state policy in New Zealand to biculturalism, and was designed to enhance Maori identity 
and improve cultural understanding (1993:14-19). But an overly technocratic attitude can stifle the ability for Crown and Maori claimants to reach an agreed outcome together. I argue the claim process causes more anxiety about identity for Maori, at both a personal and collective level than for the Crown and its officials.

Poata-Smith has been a harsh critic of the Treaty claims process, seeing itas divisive as it invites Maori to compete with one another over access to resources within a Eurocentric capitalist economic framework, which by its very nature requires inequality for its survival (2004:59, 84). Poata-Smith's point is that although Maori claimants are treated as somehow harmonious, unitary and classless, the reality of running a Treaty claim and the distribution of the benefits of a settlement only give rise to further division and tension between iwi, hapu, whanau ${ }^{2}$ and urban Maori, concentrating power in the hands of a Maori elite (ibid:77). The growth of a 'brown middle class' and a 'brown bourgeosie' has been described as a conscious and deliberate attempt by elements in the state, university and business sectors to fuse identity politics in with the neoliberal economic restructuring of mainstream politics (Edwards \& Moore, 2009:54).

While there is a lot of general theoretical analysis of the issues surrounding Treaty claims, there is not much ethnography. Toon van Meijl conducted fieldwork at a training centre offering second chance education to Maori school 'dropouts' on a marae while he was a consultant there. Van Meijl found the trainees he interviewed suffer an identity crisis and experience great difficulty in relating to representations of 'culture' being brokered by some Maori (2002:47). Such studies are highly relevant for those who are involved in the settlement of Treaty claims and the reconstruction of identity that goes with post-settlement governance. This essay focuses on the ways in which claimants grapple with questions around their own identity throughout the Treaty claims process. It draws on ethnographic research undertaken with Ngati Whatua o Kaipara ki te Tonga, a claimant group based north of Auckland city in New Zealand, spread out in small communities around the southern bowl of the Kaipara Harbour.

\section{TERMS OF REFERENCE}

Being a 'claimant' is a complexity that requires closer inspection. To claim is to, 'demand as one's due or property (to be, that one should be, recognised etc), deserve (esp. attention)' (Concise Oxford Dictionary, 1972, 6th ed.). Positioning oneself as a claimant therefore is analogous to recognising one is already 
on the back foot. Being positioned as a claimant means there is already an acknowledgement of an imbalance, a sense of due, something owing. However unlike other claims to rights or to insurance for example, a claimant under the Treaty of Waitangi Act 1975 (and its amendments) who makes a claim to acommission of inquiry, the Waitangi Tribunal, must be Maori. Claims must identify at least one individual. Claims may be brought on behalf of any group of which the individual claimant(s) are members, such as whanau, hapu, iwi trust boards, trusts, incorporations or incorporated societies, runanga or other iwi authorities. Claimants need to refer in general terms to the way or ways that the group of Maori people represented by the claimant(s) has suffered harm as a result of the Crown's actions (Waitangi Tribunal, 1993:14).

How ever, the Treaty of Waitangi Act 1975 created no legal obligation to remedy Treaty claims, thus leaving settlements to political processes through the Minister for Treaty of Waitangi Negotiations and the Office of Treaty Settlements (отs) (Law Commission Report 92, 2006:55). In order to reach settlement a claimant group definition is required, describing all those people whose claims will be settled by the settlement that results from the proposed negotiations. Such people will be eligible to become beneficiaries of the settlement. The claimant group definition usually describes a named founding ancestor (or ancestors) common to many (but not necessarily all) of the iwi and hapu, a list of iwi and hapu names (this should include all historical descent lines, even if they do not form distinct communities today), and a land area in which the ancestors of the claimant group exercised customary rights (оTs, 2002:47).

If identity has to be defined for the purpose of prosecuting a Treaty claim and has to withstand scrutiny imposed by the Office of Treaty Settlements to progress, let us look at how identity is shaped and reshaped by those processes and at what cost. Understanding the terms of reference set by the Crown enables us to reflect on the ways in which claimant identity, i.e. Maori identity, is called into question.

It is worth remembering that since historical Treaty claims span from 1840 until 1992, accumulating grievances are the norm. The Crown has stated that, 'the loss and alienation of tribal lands contributed to the breakdown and dispersal of traditional communities, and the loss of Maori language and traditional knowledge' (OTS, 2002:18). It is acknowledged that 'the loss of land undermined the connections between land and tribal and personal identity and mana $^{3}$ (ibid). Yet claimants are required to trawl through their whakapapa to identify themselves, their relationship to their kin-based communities and their connection to the land, in order to establish their rights to claim the 
status of tangata whenua (people of the land) and thus the status of claimant. Effectively the loss is officially acknowledged at the same time as it is officially ignored in the required process. Claimants are required to prove who they are time and again throughout the claims process as part of the presentation of their evidence in support of their claim, and some are more able to do this than others. Representatives of the Crown do nothing of the kind to establish the rights of the Crown to the land they claim to possess and this always seems to the claimants to be an anomaly, verging on another grievance, particularly when the Crown acquired land by way of gift from the ancestors of the claimants.

NGATI WHATUA O KAIPARA KI TE TONGA

In the case of Ngati Whatua o Kaipara, a claim was lodged in September 1992 on behalf of the members of the Reweti, Haranui, Kakanui, Araparera and Puatahi Maori Komiti and on behalf of nga hapu o Ngati Whatua o Kaipara ki te Tonga. In 1994 a claim committee was formed to lead and manage the claim process. At one time the chair of each marae komiti (committee) represented his/her marae on the claim committee. ${ }^{4}$

This claim went by the name Ngati Whatua o Kaipara ki te Tonga, a name constructed solely for the purpose of progressing a Treaty claim in a way that would satisfy the Crown's requirements in 1992 and therefore receive attention from the Crown. The Crown said it would not deal with single hapu or whanau claims. Thus it was a name chosen to identify a comprehensive claimant group covering the people from five marae communities who belong to several hapu and who retain ahikaa or close association to the land in the area. It was a name that distinguished this claimant group from Ngati Whatua o Orakei in central Auckland to the south, and Te Uri o Hau in the upper Kaipara to the north, kin groups who were running separate Treaty claims. It was also a name that caused its own people some grief because it was a made-up name, lacking in historical authenticity. However, anywhere these people went in the Maori world, they were always known as Kaipara, that much was certain. Over time the 'ki te Tonga' (to the south) was dropped.

Ngati Whatua o Kaipara elected to go through the Waitangi Tribunal process and was part of the Kaipara Inquiry, a three-staged regional approach encompassing many claims. The claim committee led a comprehensive programme of research and communications with the whanau and hapu from the marae who made up the whole claimant group, over a period of three years from 1996 
to 1999, in preparation for hearings before the Tribunal, and relied on legal counsel to conduct the case against the Crown.

WHAKAPAPA DEFINED AND DEMONSTRATED

During those Waitangi Tribunal hearings evidence of the whakapapa, origins, identity and inter-relationship of the hapu and marae was provided, in Maori and in English, by about twelve kaumatua (family elders) representing the five marae involved. In addition to the kaumatua evidence, over thirty testimonials from young and old members of the claimant group gave what was called 'socio-economic evidence' about the circumstances of their own lives and experiences. The claim committee took the Tribunal to all five marae and spoke of their connections to the area, the sites of significance to them and their issues and concerns. They showed the Tribunal the Kaipara from the air and from the sea, all the time providing a narrative of who they were and from where they came. Hundreds of whanau members listened and supported the proceedings, in spite of earlier misgivings about the process prior to the hearings. They came to help in the kitchen, to set up marquees, to record, to provide hospitality to all who came. It was a phenomenal demonstration and expression of the claimant group's identity.

For some Maori, particularly from the older generation, to speak of one's whakapapa is an essentially sacred matter. During the first hearing before the Waitangi Tribunal in March 1999 for example, one claimant refused to speak of these matters in English when asked to do so by the Tribunal. She was affronted by the fact that reciting such matters in the Maori language was not recognised as valid, so instead she asked another to interpret for her. $\mathrm{He}$ explained:

She regards herself as being a custodian, a guardian of the information she has divulged here today. They are matters which she could not herself bear to interpret because of their essentially tapu [sacred] character. It is one thing to do, as I have tried to do, to provide a line of connection between the past and the present.... The essence of what she had to say turned on what we commonly call kaitiaki or kaitiakitanga - the custodial relationship between certain individuals to whom we entrusted these responsibilities with respect to land, forests, the Kaipara [harbour], sacred places, particularly burial grounds and the spirituality inherent in certain mountains for whom she is speaking. She certainly identified herself, not only in 
terms of family name but through the issue of two key ancestors. In those terms there is absolutely no doubt about her identity as Ngati Whatua, no doubt about her right to speak on behalf of that part of the community in southern Kaipara.

Nonetheless the Tribunal insisted on translations of the kaumatua evidence presented in Maori so that it could be available for the record in an accessible form. The Tribunal said that they might need to consider competing claims using the information they had. Not only were Maori claimants having to talk about the ancestors, so too were the professional historians who had been engaged to write the history of land alienation and the socio-economic consequences of that alienation from 1840 to almost the present day. An archaeologist/GIS mapping specialist also provided details of land blocks, place names, sacred places particularly burial grounds, significant mountains and pathways. Many of the oral histories confirmed and informed the written technical evidence, and many of the ancestors' words came forth again. Indeed, as an event, one of the whanau recollected that the hearings were akin to a tangi (funeral wake):

In the fifty years of my adult association with this part of Ngati Whatua I have never seen a comparable degree of unity - except at a major tangi. It should therefore occasion no surprise if I say that the presentation of this claim is indeed a tangi; a calling up of kinship loyalty, a sharing and a release of grief, and in the aftermath, hope for reconstruction.

For many Maori, the Treaty claim process has a haunting quality about it. The legacy of the nineteenth century Native Land Court which forced tribal groups to define their claims to land through whakapapa and knowledge of ancestors, placenames, events and relationships, meant that tribal histories became highly contentious and thereafter less openly discussed (Salmond, 1985:250). For all these reasons, the Ngati Whatua o Kaipara claim committee and kaumatua had been ambivalent about how much to say in order to define themselves and their associations to the land, how to balance inclusivity with exclusivity. To define the claimant group and prove a collective identity in order to make the claim, stating that much of their collective identity had been eroded, seemed to them something of a contradiction in terms. Nonetheless, with a focus on the hope for reconstruction with the Crown's help via 'redress', the claim committee persevered. The claimant evidence brought much of what was already on the written historical record together with contemporary knowledge to construct an acceptable definition of claimant identity for the purpose of pre- 
senting the Treaty claim before the Waitangi Tribunal.

Due to the Crown negotiations and settlement with Te Uri o Hau (in the north Kaipara), in isolation from the rest of the Kaipara claims and in advance of the Tribunal reporting, the Waitangi Tribunal issued an interim report in September 2002, recommending the Crown enter into negotiations with Ngati Whatua o Kaipara. The Tribunal found that the generic historical issues raised in the Ngati Whatua o Kaipara claim were the same as those breaches of the Treaty of Waitangi and its principles already acknowledged in the Te Uri o Hau Claims Settlement Bill introduced to Parliament in 2001.

\section{MANDATE TO NEGOTIATE}

To enter negotiations a mandate to negotiate is required. A mandating process confirms the claimant group's definition of themselves and gives certain representatives the authority to begin negotiations with the Crown, on behalf of and in a way that is fair, open and appropriate to that group. In accordance with the mandating procedure as set out by отs, Ngati Whatua o Kaipara held a hui-a-iwi (tribal meeting) in August 2002 and approved the five claim committee members to initiate negotiations with the отs. The mandate was not recognised by the отs or Crown Law, but it was not clear why and for six years there was practically no engagement between Ngati Whatua o Kaipara and the Crown. The отs insisted that the mandate be reconfirmed because it deemed there to be overlapping interests.

OTS's policy changed in 2002 to negotiating with a comprehensive 'large natural grouping', which comprised all that group's historical claims against the Crown, even when those claims may have been presented separately to the Tribunal. The policy was said to make settlements easier, more manageable and cost-effective, and more durable in the sense there might be less likelihood of challenge to the settlement package. Under this policy the Crown persuaded itself that the Crown-constructed iwi authority, Te Runanga o Ngati Whatua, was the most appropriate body with whom to negotiate and settle all remaining Treaty claims within Ngati Whatua.

As a result Ngati Whatua o Kaipara appealed to the Waitangi Tribunal for a remedies hearing in 2006 which effectively threatened the Crown with litigation. Finally, in February 2008, the Minister ${ }^{5}$ agreed that both Kaipara and Te Runanga o Ngati Whatua could progress their respective settlement negotiations, each as large natural groupings. In June 2008 Ngati Whatua o Kaipara signed a Terms of Negotiation, but by November negotiations stopped again 
due to national elections. After a change of government in 2008 the policy changed again to a regional collective of claims. Ngati Whatua o Kaipara found themselves dependent on a parallel process with iwi and hapu in the Tamaki and the Hauraki ${ }^{6}$ regions, as well as being part of a larger Kaipara region in order to be able to commence settlement negotiations. The Crown accepted claimant groups who, although regionally clustered, had neither completed research to substantiate their claims nor achieved a mandate to account for their ability to represent a group of people, but accepted them nonetheless because it was a means of seeking to provide comprehensive finality for the Crown.

At the core of this struggle to progress to the next stage of the claim process were questions being asked by the отs over the rights of the claimants to claim, and the validity of their claimant group definition for determining the extent of their identity. In other words, the claimants' identity was on slippery ground. отs wanted to argue that until the claimant definition and mandate were in the form determined by отs, negotiations for items of redress were on hold. At one level the conversation was technical; it was about ticking boxes of procedure. But at another level, there was a struggle between the parties to gain mastery over the terms of the engagement, terms that the Crown/отs regulated (Comaroff \& Comaroff, 1991:199).

\section{PROSPECT OF SETTLEMENT}

Much of the Treaty claim negotiation process for any claim committee is a struggle to engage with the Crown in a sustained and constructive way. Once engaged however, much of the process is driven by the Crown's need to ensure the people with whom it is dealing are representative of and accountable to a wider group, hence the attention paid to claimant definition and mandate. But the ultimate aim of negotiations is settlement and redress. In order to achieve settlement, a post-settlement governance entity must be established. It is a legal, bureaucratic structure whose main decision-making process is democratic via postal ballot but whose electorate is to be determined by kinship and descent. In the case of Ngati Whatua o Kaipara, the burden of designing the new structure to manage collective assets in ways consistent with Maori, specifically Ngati Whatua cultural values, fell to the claim committee and legal counsel, but the critical question was whether this would be possible.

Settlement inevitably carries different expectations for the Crown than it does for a group like Ngati Whatua o Kaipara, although both would agree settlement is meant to be a restorative process. According to the Office of Treaty Settlements, settlement: 
- is intended to remove the sense of grievance

- is a fair, comprehensive, final and durable settlement of all the historical claims of the claimant group, and

- provides a foundation for a new and continuing relationship between the Crown and the claimant group, based on the principles of the Treaty of Waitangi (отs, 2002: 84).

In practice this means that a settlement package includes three core areas of redress:

1. the Crown recognises and accepts responsibility for the wrongs done through the historical account, Crown acknowledgements and apology;

2. the Crown provides financial and commercial redress, which is given a monetary value called quantum, in recognition of breaches by the Crown of the Treaty of Waitangi and its principles. The quantum can be used to build an economic base for the claimant group; and

3. the Crown provides redress recognising the claimant group's spiritual, cultural, historical or traditional associations with the natural environment, sites and areas within their area of interest - often called cultural redress (ibid.).

A Deed of Settlement (DoS) between Ngati Whatua o Kaipara and the Crown was signed in September 2011. Settlement legislation is going through Parliament at the time of writing (2013) and assets have yet to transfer. It has been more than a twenty year project. For the Ngati Whatua o Kaipara claim committee, settlement of their Treaty claim has meant many things. Probably the most obvious was the fact of bringing the claim to its conclusion against, what must have seemed at times, all odds. Settlement then brought a sense of relief that the struggle was over. But the return of land will be far more significant; as one member noted, 'it's the spiritual life of the people really by getting it [the land] back.' Another member saw land returned as an appropriate close to the spiritual sacrifice, for the 'blood shed for the whenua.' For him, 'our sustenance comes from the land, if you've got no whenua, you've got no mana.'

Settlement of the claim for the claim committee was expected to align with some core principles at the heart of a Maori world-view. Having land returned to those entrusted with it restores mana and self-respect in various ways. Firstly, it restores the imbalance caused by those who 'shed blood' for the land, either literally or metaphorically speaking. Secondly, it restores the imbalance in the relationship with the Crown, a relationship perceived to be of the utmost importance for Maori, and which both parties to the Deed of Settlement have 
agreed to continue. Thirdly, it helps restore the group's capability to reciprocate, to offer manaakitanga (hospitality, care), an integral part of interactions, not only in an on-going relationship with the Crown but also with other groups, both Maori and non-Maori. Land is, of course, of practical value too, capable of providing a place for dwellings, marae complexes, income, employment, and much more. As Metge (2002) explained about the principle of utu, a negative cycle of exchange is turned into a positive one by symbolically giving good gifts' - it is fulfillment of the unrequited debt. For the claim committee, settlement confirmed that the principle of utu is a valid principle for social interaction between the Crown and themselves, not least because the nature of the on-going relationship has been written into the settlement agreement.

One claim committee member stated quite clearly that his motivation for lodging the claim was 'for the importance of our continuing existence of ourselves in Kaipara, and ...for you [non-Maori in general] to acknowledge that I'm tangata whenua.' It is expected therefore that a Treaty settlement enshrined in statute ultimately will recognise the status and identity of Ngati Whatua in the south Kaipara, in New Zealand society and at local and national governmental levels. Thus tribal identity as well as individual identity in Maori terms will be reconfirmed more positively, especially for those for whom being Maori has felt to be in some way a disadvantage.

SHAPING A POST-SETTLEMENT GOVERNANCE ENTITY

The OTs Guide (2002) sets out the principles for a post-settlement governance entity structure as being one that:

- adequately represents all members of the claimant group

- has transparent decision-making and dispute resolution procedures

- is fully accountable to the whole claimant group

- ensures the beneficiaries of the settlement and the beneficiaries of the governance entity are identical when the settlement assets are transferred from the Crown to the claimant group, and

- has been ratified by the claimant community. (2002:72)

It is argued by отs that ensuring the governance entity meets these principles means that the Crown is being responsible to all New Zealanders, including all members of a claimant group, by ensuring the settlement assets are managed for and by those who rightfully benefit from the settlement. The отs Guide also states that the claimant group can choose a governance entity that will serve their needs and reflect their tikanga (custom) but adds the range of op- 
tions to choose from is relatively small (2002:71-72). The Crown cannot transfer settlement assets to a claimant group until their governance entity has been approved by the Crown Law Office, ratified by postal ballot and established by the election of representatives.

When the claim committee communicated the proposed governance entity structure to the claimant group in a series of hui or meetings on the marae, people were faced with a complexity of issues. The proposal was seen as a Crown device designed to reconstruct the claimants' reality, and the claim committee was seen as both powerless to change the proposal, and being in agreement with the proposal. To some extent the claimant group was right on three counts. The best the claim committee could do to achieve the goal of settlement was to modify the отs requirements for a governance entity.

The most obvious pitfall of the newly created governance entity in Ngati Whatua o Kaipara's case was for it to be perceived by the claimant community as replacing the bureaucracy of the Crown, which many claimants found oppressive, with another equally patronising bureaucracy of the claimants' own making. Therefore what was at stake here for the claim committee was to obtain yet another mandate to govern, by individual postal ballot from all members of the claimant group as defined by kinship and descent who had registered to vote, irrespective of residence or participation in the group, in order to obtain recognition from the government of the day. In spite of the alienation and dislocation from the land in the area, and the sense of disenfranchisement and marginalisation for many of the descendants, as documented in the claim evidence, bringing the Treaty claim to fruition required bringing the claimant group back together again.

The role of tikanga in this part of the process was highly questionable. The leadership on the claim committee as respected kaumatua and representative claimants leading the Treaty claim on behalf of their marae communities, had an inherent dilemma. Respected kaumatua or not, it could not be taken for granted that those members would continue to lead the newly established governing body which was to receive and manage the settlement assets. Their leadership was at the mercy of the decision-making of the majority of voters many of whom lived elsewhere.

In this event, the draft governance entity trust deed was amended to grant the five claim committee members, as marae representatives, an initial term of two years. Three new general members, not obligated to any one marae, were elected by postal ballot for a four year term and together they signed the Deed 
of Settlement. A Nohoanga Kaumatua or advisory body was to be established for kaumatua and retired members to enable them to have ongoing input to major decisions of the governance entity. The strain of the claim process for these retiring members was acknowledged, particularly as most of them were aged in their late sixties and seventies, and the work of the new governance entity would necessarily focus on sound financial investment practices which might suit a younger, more professional kind of representative. On the other hand, elected representatives might come from anywhere, with no proven track record in the community, and no understanding of the history, the land or the people, but simply by a majority of votes, from those who cast their vote. The great fear constantly reiterated at hui was that only a few would benefit from the settlement, and no transformation would occur on the ground. Nothing would change for the better. Or worse, the one opportunity the claimants have to advance would be wasted by ignorant, irresponsible or unscrupulous representatives.

While the отs held up democratic forms of governance as the way forward for Maori claimant groups to organise themselves and manage tribal assets, for many Ngati Whatua the proposal was a folly, particularly for those whose experience attested to just how undemocratic and unjust the practice of democracy could be. People were familiar with political lobbying and block voting as tactics to get around the democratic ideal of 'one man, one vote. The draft governance entity trust deed was therefore amended to insist on candidates for marae representatives presenting themselves at their own marae prior to election.

PROPOSED POST-SETTLEMENT GOVERNANCE ENTITY

A series of consultation hui on each of the marae (fifteen in total) over the two year period and feedback from those hui helped the claim committee and legal counsel refine the proposed entity. Figure 1 provides a visual of the finalised structure. The double trust structure separates and protects lands which are not available for commercial enterprise from those that are.

A final hui to confirm seven key components of the proposed governance structure for subsequent ratification by postal ballot was held on one of the marae in July 2009. Forty five people attended the hui. Here I discuss two of the seven key components; the name of the entity, and the recognition of ancestral connections between people and land, to show the reconfiguring of identity claimants must attend to in this process. 


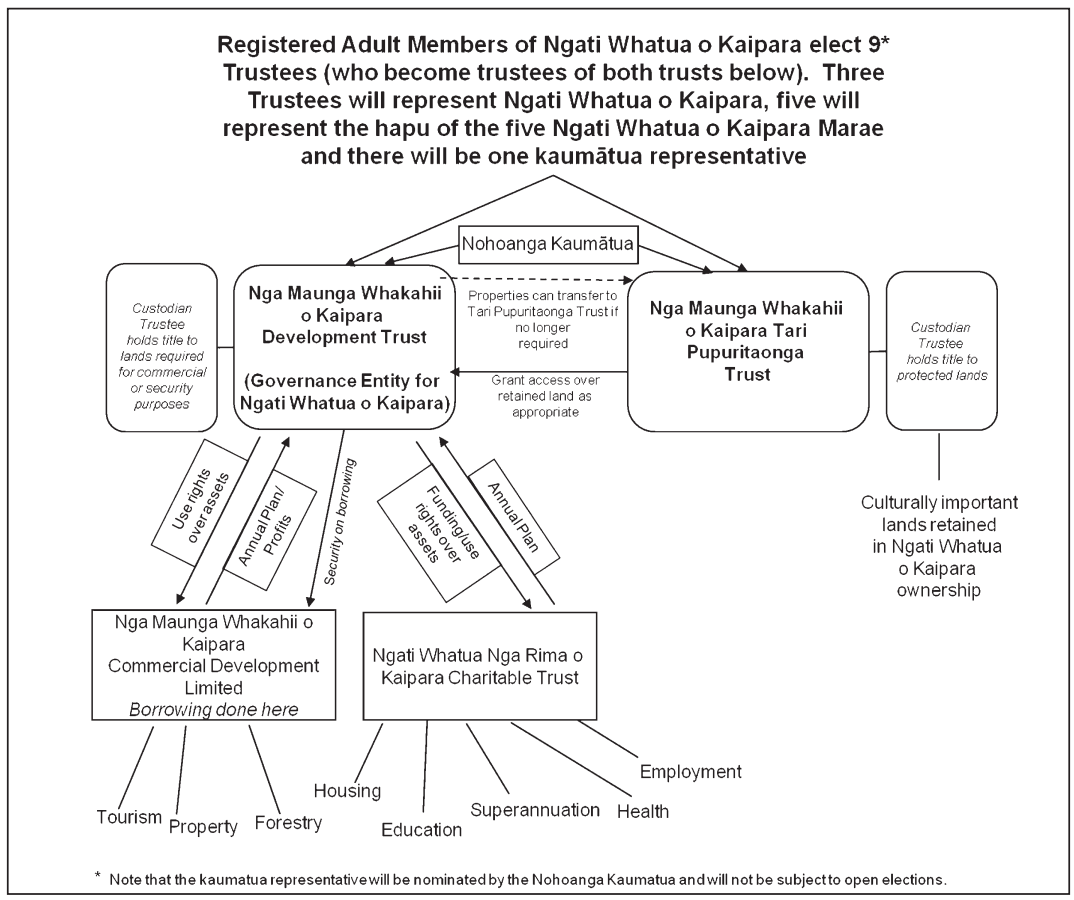

Figure 1. Proposed Post-Settlement Governance Entity (2009)

\section{NAME OF GOVERNANCE ENTITY}

The first proposition was 'That Nga Maunga Whakahii o Kaipara be adopted as the name the claimants are referred to by, and included in the proposal to be put to the postal ballot.' Throughout the claim, the claimants had been referred to as Ngati Whatua o Kaipara ki te Tonga, and more recently just Ngati Whatua o Kaipara, sometimes even simply Kaipara. Those names were intended to include the five named claimants, i.e. the five original members of the claim committee, who stood on behalf of the people of the hapu known as Te Taou, Ngati Whatua Tuturu, Ngati Rango and that part of Ngati Hine who descended from Mate, who affiliated to the five marae in the area at Reweti, Haranui, Kakanui, Araparera and Puatahi. As this grouping encompassed a number of aggregations, whanau, marae, hapu, and the overarching values were inclusivity and unity, a name for the new organisation, Nga Maunga Whakahii o Kaipara, was proposed and explained as follows: 
Ka timata ahau i te tihi o Atuanui, te maunga whakahii tenei o Te Manawanui, te Marae o Puatahi, ka huri taku titiro ki te tihi o Taranaki te Maunga korero tenei o te Pa o Te Aroha kei Araparera, wahoatu i tenei ko Tuhirangi maunga, te tokakamaka o Kakanui O Paneira, kei raro iho, ko te Marae o Te Kia Ora, kei wahoatu i tenei ko Tauwhare maunga e toha nei ki te tai whakararo, ko tenei te Maunga korero o Whiti Te Ra, te Marae o Reweti. Ka hurite titiro ki te hauauru ko te Maunga Tarawera, te maunga korero o Nga Tai i Turia ki te MaroWhara, te Marae o Haranui.No reira ko Ngati Whatua o Kaipara tenei e ngunguru nei, e ngunguru nei.Ko nga rarangi maunga tu tonu, tu tonu, tu tonu, te rarangi tangata ngaro noa, ngaro noa, ngaro noa.

I begin from the peak of Atuanui, the astute mountain of $\mathrm{Te}$ Manawanui, the marae of Puatahi; I turn and look towards the peak of Taranaki, the mountain of communication to Te Aroha Pa at Araparera; outside of this I see mount Tuhirangi, the rock mountain of Kakanui o Paneira and Te Kia Ora Marae; further out there is Tauwhare, the mountain of communication to Reweti Marae, Whiti te $\mathrm{Ra}$; I gaze westward to see mount Tarawera which is the mountain of communication for Nga Tai $i$ Turia ki te MaroWhara, the marae of Haranui.This is Ngati Whatua o Kaipara. The status and rank of the mountain will always stand, but that of mankind will wither away.

The thinking behind this proposed name was forward-looking but with an emphasis on one of the key traditional indicators of identity, one's connection to a maunga (mountain), no matter where one lives or to what degree one participates in local affairs. It was also a way to include everyone without delving into the intricacies of whakapapa explicitly.

Carter's (2001) thesis called Whakapapa and the State is an-depth study of modern iwi governance systems and their effect on whakapapa as an organisational framework in Maori societies. Her question is whether whakapapa as an organisational process can survive, or will it be stifled as Maori struggle to establish a strong identity in contemporary New Zealand. Carter cites a number of stories of the connection between maunga and whakapapa. For example:

The maunga link the whakapapa. When the maunga calls, the chief will hear it and know what the message is. Before phones, communication was through the maunga. Te Pere o Te Tairawhiti [speaker's grandson] is linked to all the whakapapa of the East Coast and 
therefore links to all those outside. He was named to recognise the linking of the maunga, therefore the hapu, therefore nga whenua, ngamahinga kai me etahi ake ngā mea [the land, places for gathering food and resources and all other such things]. To 'te pere' is to send out a message and one maunga would send a message to another and so on. (Maruhaeremuri Stirling, cited in Carter, 2001: 83)

Koro Pei used to stand and call out each of the maunga - the name of the maunga, the hapu connected with it. It was done to remember all the obligations, all the relationships between the hapu - the maunga are the key; they form the matrix across the land. (Miki Roderick, cited in Carter, 2001: 83)

In light of the new name being offered, Nga Maunga Whakahii o Kaipara, these stories supported the suggestion as being a skillful one for they showed how maunga represent relationships (Carter, 2001: 84). Carter explains that maunga can be considered to be whakapapa when it is 'recited to recall relationships between the three worlds of whakapapa: whakapapa atuatanga, or the origin and spiritual principle; whakapapa tangata, or the human principle; whakapapa putaiao, or the principles of survival' (ibid).

Herein lies the depth and complexity of the practice of whakapapa, which for many Maori is a very sensitive issue. It is considered by some to be knowledge that should only be handed down to and recited by specialists, tohunga (spiritual leader) and rangatira (acknowledged leader), for its own protection and for the survival of the group. There is evidence of whakapapa being used in the Maori Land Court in relation to land claims, and being used divisively. Whakapapa can also reveal parentage that can be interpreted as being less Maori or not proper Maori. Prior to the 1986 census, statistical definitions of Maori were on the basis of biological criteria; only those who were half or more Maori' were deemed by legislation to be Maori.

The long term effect of a legal, rational, bureaucratic standardisation of Maori identity which does not accept a whakapapa-based knowledge system in all its fullness, has been alienation for many Maori, dissuading them from organising themselves on a whakapapa basis at all. Consequently there is a risk that knowledge of whakapapa is sketchy, personalised and perhaps inaccurate. While there is superficial mention of whakapapa as being the organising principle for the beneficiary register for the claim, no further layers of obligation, responsibility, and relationship are articulated or practised on the basis of whakapapa. Eligibility to vote as a member of Ngati Whatua o Kaipara gives 
no guidance as to how to relate to others in the group, how to participate or contribute to the maintenance of the marae, how to behave at key events like tangi for example. The pressure and tension inherent in the claim process to achieve settlement without further delay or loss of the compensation owing to the claimants has placed the claim committee in a quandary. While each has an understanding of whakapapa, much of it I suggest is embedded and shaped by lived experience, and it has not been easy for them to articulate how whakapapa might be used as a system of social organisation in Maori, let alone in English.

The hui accepted the name but what they did not accept was to continue to be called 'claimants'. There was also a view expressed that the name should be a familiar one coming from the shared history. The name was to be for the new governance entity that had to be established for the purposes of receiving and managing the Treaty claim settlement. The settlement was expected to be worth over $\$ 6$ omillion in land, quantum, accumulated rentals from the forest, carbon credits and revenue-producing assets, and it was intended to be of benefit to all those who are entitled. Whether or not settlement spelled success or whether settlement was even necessary to establish mana were debatable points. However a distinction was made between the corporate nature of managing these commercial affairs, and managing tikanga, cultural integrity and continuity, which properly rests with the whanau, hapu and marae. The newly elected representatives to the new entity were seen as trustees over the claim settlement, not over anything else, and there was a fear that the governance entity would be perceived to be the spokesbody for Ngati Whatua o Kaipara collectively, and once again the people located at whanau, hapu and marae level would be marginalised. The fact that they, individually, had registered on the required beneficiary roll was not considered sufficient to be a successful candidate. They would be required to withstand scrutiny prior to election on their marae and report back to their marae on a regular basis during their term of trusteeship.

An example of how these organisational names can come to distort reality was cited at the hui. Another organisation, representative of the same five marae as the claim, and set up to deal with primarily local government and social contracts from government agencies, was called Ngati Whatua Nga Rima o Kaipara. Imagining this name to be the name for the iwi, someone had been heard using it to state their tribal identity, 'Ko Nga Rima toku iwi' meaning Nga Rima is my tribe; an innocent but unfortunate mistake. There is a strong argument for creating the appropriate space in which to allow people to explore aspects of their history, language and lore, and to see how these may be applied 
to an ever shifting reality and metamorphosis of their social organisation.

\section{RECONNECTION WITH CULTURALLY IMPORTANT LANDS}

The sixth key proposition of the proposed governance entity was: 'That the trust deeds will provide that a key objective for both trusts will be to facilitate reconnection of claimants with lands within the claim area and include mechanisms to facilitate this occurring, and that this be included in the proposal to be put to the postal ballot'.

But like the first proposition, it had caused considerable angst among the claim committee and taken a great deal of thought to work out. As explained by one member, it is 'an accident of history that [...] Forest is the only major commercial redress asset in the area.' In other words, in spite of the Crown admitting to wrong-doing over the acquisition of much of the land in the claim area in the nineteenth century, the fact that it had on-sold most of the land meant there was only so much land left in Crown ownership to return as redress to claimants who had proven their case, because privately-owned land is not used in settlements. But one whanau in particular felt a very strong sense of belonging to part of the land in the redress package for this claim.

\section{A WHANAU CLAIM}

The Crown had permitted one whanau to lodge a claim with the Waitangi Tribunal, and had heard their grievances at a separate hearing, alongside the hearings of the whole claimant group in the south Kaipara area. The Waitangi Tribunal had reported in the Kaipara Report that:

The claimants feel strongly about the seeming failure of Crown officials to acknowledge their view of the world. [The claim] was heard in a tent ..., on the site of the former Forest Service village rubbishtip. This is just below the site of the ancestral [...] Pa, which had been planted in pines. The choice of the site was deliberate, despite the difficult access, the wind, and the rain, because the claimant [...] wanted to express his feelings that the mana and identity of his whanau as tangata whenua had been eroded, that their ancestral pa had been desecrated, and that so little remained of their ancestral lands. (Waitangi Tribunal, 2006:327)

The Waitangi Tribunal recommended that the whanau claim be included in the overall settlement of Ngati Whatua o Kaipara land claims and that any 
Crown land taken under the Public Works Act from [Block A] that was no longer required for any public purpose should be revested in the owners of the block (ibid.). So when it came time to negotiate the settlement of the claims, there was one settlement package for all and one governance body. Worse, the governance entity proposed was made up of representatives from the five marae only. The Wai numbers given to the claims upon registration with the Waitangi Tribunal, (for example Wai 312), had disappeared. The Crown had made a unilateral decision in February 2008 that there would be only two more settlements within Ngati Whatua. If a whanau claim did not wish to join one large natural grouping, it had the choice of joining the other to be represented. Separate settlements for whanau claims were clearly not possible. This was a blow to the whanau who had always believed they would receive recognition and compensation for their grievances. Furthermore, it had been an airing of their particular grievances among the kaumatua from the five marae that had, in part, first initiated the idea of lodging claims against the Crown. So the obvious question for the whanau now was where did they fit, what place did they have?

When the whanau met face to face with the Crown negotiator they stated that their grievance was that the proposed governance entity was not structured to include their representative and they did not want to be part of it. They did not want the land to be held by trustees who had no link to the land. The Crown negotiator confirmed that it was highly unlikely the Crown would settle the whanau claim separately, in spite of the fact that the Crown had agreed to settle another whanau claim who had even less interest in the same area. The Crown's explanation for this was that they had determined that whanau to be what they called 'an overlapping claim'. The difficulty for this whanau was that they were part and parcel of both claims; their own whanau-specific claim and the wider overarching claim led by the claim committee.

\section{A BALANCING ACT}

All that the Crown negotiator suggested was that a conversation between the whanau and the claim committee would be useful. But by putting the onus back on the claim committee, the Crown failed in its responsibility to the claimants, for a Treaty claim is not directed at other claimant groups but at the Crown. By being conciliatory, the Crown negotiator failed to set out Crown policy clearly for the whanau. The reality of this settlement package was that it was not, and could not be, a full compensation for 'damages'. It was only a fair level of redress for all the grievances within the area, the benefits of which must be shared by all those entitled. In no settlement had there been a division 
of the asset, nor could there be without privatising it. But the question of realigning mana struck at the core of the comprehensive Ngati Whatua o Kaipara settlement. The primary concern for the claim committee was to reconcile the wider group interests with the concerns of the individual and his whanau. In other words it was a balancing act between maintaining the wider grouping's survival, integrity and cohesion with specific ancestral connections to place, from which individuals could derive mana and in this case, their standing as a Ngati Whatua person.

'In practice, descent divides, because it appeals to mana and privilege, whereas kinship unifies, because it appeals to aroha and co-operation' according to Kawharu (1975:71). Although there has always been conflict between these forces, that conflict is unlikely to lead to a permanent break in relations, for inevitably there are times when it is in everyone's best interests to combine forces (ibid.). Indeed the long road to settlement has demanded kinship (whanaungatanga) and unity (kotahitanga), both of which rest on a shared understanding of whakapapa. This particular debate brought about an innovative improvement to the structure of the proposed governance entity by emphasising reconnection of claimants with their ancestral lands within the claim area. The trust deed provided for kaitiaki (custodian) who would be appointed to look after certain lands received in settlement, and no lands would be developed or disposed of, or otherwise alienated, without taking account of those who have particular interests in those culturally important lands. Furthermore, at the request of owners of existing Maori land, ways would be developed to reconnect people with their traditional lands that were practical, affordable and sustainable.

\section{CONCLUSION}

The way in which this claim committee has worked through all the requirements imposed upon them has been to empower their people by encouraging participation and ownership of the process as much as possible. It has been by acknowledging everyone with respect, by taking a long-term perspective, by the use of consensus decision-making on the marae, endless discussion among themselves, and working with conflict as a means to engage people, that the identity of the group has been constantly remade and thus perhaps made more resilient. But there is no doubt it is the Crown who has controlled the Ngati Whatua o Kaipara claims process. By the time the claimant group had made its way to settlement, it had been required to reconfigure its tribal identity, and its families and individual members reinvent themselves. Underpinning their deliberations lay the question of whether this post settlement governance en- 
tity mechanism would achieve meaningful and substantial self-determination, and a new-found Ngati Whatuatanga. And if not this structure, what was the alternative? The issues at stake have been complex and involved balancing the need to retain a connection between past and present, and a distinctive identity grounded in whakapapa and tikanga, and the need to demonstrate sufficient organisational sophistication so as to be able to function alongside the Crown, and be politically empowered. My observation of these deliberations has also raised a question around the options that are available to the claimants, when the cultural traditions have been so impacted by both colonisation and the resistance to it. It is clear that post settlement for Ngati Whatua o Kaipara is still very much 'a work in progress' and a metamorphosis.

\section{ACKNOWLEDGEMENTS}

I am honoured to have received a scholarship from The Ngarimu VC and 28th (Maori) Battalion Memorial Scholarship Fund Board for two years, 2008-2010. My sincere appreciation goes to the Board for their financial assistance. I remain forever in the debt of those of my family who served in the World Wars: Wiremu Paora, Lu Paul and Louis Nathan.

\section{NOTES}

1 Notion of 'the Crown' based on the other party who signed the Treaty of Waitangi in 1840 . Today the Crown is represented by the government of the day.

2 Iwi - large socio-political grouping defined by descent from a named ancestor; hapu - sub-tribe or descent group; whanau - extended family group.

3 Authority, prestige, standing, proven ability to get things done.

4 The basis for this essay is field-work carried out part-time over two years in 2008-9 with this particular claimant group and claim committee, during an intensive period in their negotiations with the Crown. Apart from the research for an MA thesis, I held the role of claim manager from 1995-2011, and belong to the claimant group by virtue of my own whakapapa.

5 Minister in Charge of Treaty of Waitangi Negotiations, at the time in February 2008, was Hon. Michael Cullen.

6 Greater Auckland and Coromandel regions. 
7 Principle of reciprocity, return for something received, compensation, countergift.

\section{REFERENCES}

Carter, L. 2001 Whakapapa and the State. Unpublished PhD thesis, Auckland: Auckland University.

Comaroff, J. and J. Comaroff. 1991 Of Revelation and Revolution: Christianity, Colonialism, and Consciousness, Vol. One. Chicago: The University of Chicago Press.

Edwards, B. and J. Moore. 2009 'Hegemony and the culturalist state ideology in New Zealand', in R. Openshaw and E. Rata (eds) The Politics of Conformity in New Zealand, Auckland: Pearson.

Kawharu, I.H. 1975 Orakei: A Ngati Whatua Community, Wellington: New Zealand Council for Educational Research.

Law Commission. 2006 Waka Umanga: a proposed law for Maori governance entities (Report, 0113-2334; 92).

Meijl, T van. 2002 'Culture and crisis in Maori society: the tradition of other and the displacement of self', in E. Kolig and H. Muckler (eds) Politics of Indigeneity in the South Pacific: Recent problems of identity in Oceania, Hamburg: Lit Verlag: 47-71.

Metge, J. 2002 'Returning the gift - utu in intergroup relations, in memory of Sir Raymond Firth', Journal of the Polynesian Society: III(4):311-338.

Office of Treaty Settlements. 2002 Guide to Treaty of Waitangi Claims and Negotiations with the Crown, Ka tika a muri, ka tika a mua, healing the past, building a future, Wellington: Minstry of Justice

Poata-Smith, E. 2004 'Ka tika a muri, ka tika a mua? Maori protest politics and the Treaty of Waitangi settlement process', in P. Spoonley and C. Macpherson and D. Pearson (eds) Tangata Tangata: The Changing Ethnic Contours of New Zealand, Australia: Thomson/Dunmore Press.

Salmond, A. 1985 'Maori epistemologies', in J. Overing (ed) Reason and Morality, London \& New York: Tavistock Publications. 
Article $\cdot$ Kawharu

Scott, J.C. 1998 Seeing Like A State: How Certain Schemes to Improve the Human Condition Have Failed, New Haven and London: Yale University Press.

Sissons, J. 1993 'The systematisation of tradition: Maori culture as a strategic resource', Oceania, 64(2):97-116.

Waitangi Tribunal. 1993 A Guide to the Waitangi Tribunal, Wellington: Ministry of Justice

2006 The Kaipara Report, Wellington: Legislation Report. 